\title{
Livin enhances tumorigenesis by regulating the mitogen- activated protein kinase signaling pathway in human hypopharyngeal squamous cell carcinoma
}

\author{
SUN-AE KIM ${ }^{1}$, TAE MI YOON ${ }^{1}$, DONG HOON LEE ${ }^{1}$, JOON KYOO LEE ${ }^{1}$, YOUNG-LAN PARK ${ }^{2}$, \\ IK-JOO CHUNG ${ }^{2}$, YOUNG-EUN JOO ${ }^{2}$ and SANG CHUL LIM ${ }^{1}$ \\ Departments of ${ }^{1}$ Otorhinolaryngology-Head and Neck Surgery, and ${ }^{2}$ Internal Medicine, \\ Chonnam National University Medical School, Gwangju 501-757, Republic of Korea
}

Received June 15, 2015; Accepted April 20, 2016

DOI: $10.3892 / \mathrm{mmr} .2016 .5242$

\begin{abstract}
Livin, a member of the human inhibitor of apoptosis protein (IAP) family, is expressed at high levels in various human cancer tissues and may have prognostic significance. The aim of the present study was to evaluate the effect of Livin on tumor cell behavior and oncogenic signaling pathways in human hypopharyngeal squamous cell carcinoma (HSCC). Reverse transcription-quantitative polymerase chain reaction and western blot analyses were used to determine the mRNA and protein expression levels, respectively. A cell proliferation assay and cell cycle analysis were used to assess the functional effects of small interfering RNA-mediated Livin knockdown. Livin was overexpressed in fresh HSCC tissues, compared with the adjacent normal mucosa. Livin knockdown led to significantly reduced cell proliferation and cell cycle arrest in the $\mathrm{G}_{1}$ phase of the human HSCC cells. The expression levels of c-myc, cyclin D1, cyclin D3, cyclin-dependent kinase (CDK)4 and CDK6 were decreased. The phosphorylation levels of extracellular signal-regulated kinase $1 / 2$, p38, c-Jun N-terminal kinase and Akt were also decreased by Livin knockdown in the HSCC cells. Taken together, the results of the present study suggested that Livin may enhance tumorigenesis by modulating the mitogen-activated/Akt signaling pathways in human HSCC.
\end{abstract}

Correspondence to: Professor Tae Mi Yoon, Department of Otorhinolaryngology-Head and Neck Surgery, Chonnam National University Medical School, 8 Hak-Dong, Dong-Ku, Gwangju 501-757, Republic of Korea

E-mail: yoontm@chonnam.ac.kr

Key words: livin protein, hypopharyngeal cancer, carcinogenesis, molecular targeted therapy, mitogen-activated protein kinase kinases

\section{Introduction}

Hypopharyngeal squamous cell carcinoma (HSCC) is less prevalent, compared with cancer at other major sites of the head and neck, including the oral cavity, larynx and oropharynx, with $<3,000$ cases reported in the United States annually (1). The majority of patients with HSCC present with significant comorbidities and advanced stages of disease. The anatomical proximity of the larynx, advanced stage of disease at presentation, and higher rates of regional and distant metastases result in poor rates of prognosis. These factors require consideration when making treatment decisions. Traditionally, laryngopharyngectomy with reconstruction of the pharynx has been the preferred initial treatment for locally advanced operable HSCC. Efforts to preserve vocal and swallowing functions have resulted in surgical organ-preserving procedures with improved reconstructive efforts and/or chemoradiation. Despite advances in surgical methods, chemotherapy and radiotherapy, the prognosis of patients with advanced HSCC has not shown satisfactory improvement (2-4). Therefore, in order to provide more effective treatment to patients with advanced HSCC, otolaryngologists have increasingly focussed on novel treatment modalities, including molecular-targeted therapies.

Livin is a member of the human inhibitor of apoptosis protein (IAP) family (5). The IAPs comprise a group of structurally related proteins with anti-apoptotic potential $(6,7)$. The IAPs may be involved in preventing tumor cell apoptosis and, therefore, may contribute to tumorigenesis $(8,9)$. High expression levels of Livin in neoplasms correlate with more aggressive behavior, leading to shorter disease-free survival rates, shorter overall survival rates and chemoresistance $(8,9)$. Furthermore, Livin is expressed at high levels in various human cancer tissues (8-10). Therefore, Livin has become the focus of substantial investigations, however, the role of Livin in human HSCC remains to be fully elucidated.

Several of the molecular alterations associated with tumorigenesis occur in cell signaling pathways, which are responsible for regulating cell proliferation and apoptosis. The exact mechanism underlying the anti-apoptotic action of Livin remains to be elucidated. The mitogen-activated protein 
kinase (MAPK) pathway is involved in the regulation of cellular functions, including cell proliferation, differentiation and death $(11,12)$. Several studies have reported that the activation of MAPK has a functional role in carcinogenesis $(13,14)$. However, the impact of Livin on MAPK signaling remains to be elucidated.

In the present study, the gene expression of Livin was examined in fresh tissues of advanced cases of HSCC. The present study also investigated whether Livin affects tumor cell proliferation, cell cycle progression and oncogenic signaling pathways, including MAPK and Akt signaling, in human HSCC cell lines. This study may provide the basis for the application of Livin as a molecular targeted therapy for HSCC.

\section{Materials and methods}

Patients and tumor specimens. Fresh HSCC tissues and paired normal hypopharyngeal mucosal tissues were collected from four patients (males; aged 50-75 years old) who underwent definitive surgery for HSCC at Chonnam National University Hwasun Hospital (Jeonnam, Korea). The protein and mRNA expression levels of Livin were analyzed in these HSCC tissues and paired normal hypopharyngeal mucosal tissues. The study was approved by the ethics committee of the Institutional Review Board of Chonnam National University Hwasun Hospital (Gwangju, Korea). Written informed consent was obtained from each patient prior to tissue acquisition.

Cell culture and transfection. The human HSCC cell line, SNU-1041, was provided by Dr. Sung MW (Seoul National University, Seoul, South Korea). The cells were cultured in RPMI 1640 medium (Invitrogen; Thermo Fisher Scientific, Inc., Waltham, MA, USA), supplemented with $10 \%$ fetal bovine serum (GE Healthcare Life Sciences, Logan, UT, USA), in a humidified atmosphere of $5 \% \mathrm{CO}_{2}$ at $37^{\circ} \mathrm{C}$. Small interfering RNA (siRNA) was used to knock down the endogenous gene expression of Livin in SNU-1041 cells. SNU-1041 cells were seeded onto 6 -well plates at $2 \times 10^{5}$ cells/well and transfected with Livin-specific siRNA (Bioneer, Daejeon, Korea) or negative control siRNA (Qiagen, Germantown, MD, USA), using Lipofectamine RNAiMAX (Invitrogen; Thermo Fisher Scientific, Inc.) for $48 \mathrm{~h}$ at $37^{\circ} \mathrm{C}$.

Cell proliferation assay. The cells were seeded into a 96-well plate $\left(10^{3}\right.$ cells/well) and, the following day, were transfected with Livin siRNA and negative control siRNA. Following incubation for $24 \mathrm{~h}$ at $37^{\circ} \mathrm{C}$, cell proliferation and viability were measured using an EZ-CyTox (water-soluble tetrazolium salt; WST-1) cell viability assay kit (Daeil Lab, Inc., Seoul, South Korea) at 0, 24, 48 and $72 \mathrm{~h}$. Following the addition of WST-1 reagent for $1-2 \mathrm{~h}$ at $37^{\circ} \mathrm{C}$, the absorbance at $460 \mathrm{~nm}$ was determined using a microplate reader (Infinite M200; Tecan, Austria GmbH, Austria) with Magellan V6 data analysis software (Tecan). The ratio of the absorbance of the transfected cells to that of the negative control cells at $0 \mathrm{~h}$ was calculated.

Cell cycle analysis. The cells transfected with Livin siRNA or negative control siRNA were collected using trypsin, washed with cold phosphate-buffered saline (PBS) and fixed in ice-cold
$70 \%$ ethanol to determine cell cycle distribution. The fixed cells were washed with PBS and resuspended in $0.1 \%$ sodium citrate, $0.1 \%$ Triton $\mathrm{X}-100$ and $50 \mu \mathrm{g} / \mathrm{ml}$ propidium iodide for $20 \mathrm{~min}$ at room temperature in the presence of $10 \mu \mathrm{g} / \mathrm{ml}$ ribonuclease A (Sigma-Aldrich, St. Louis, MO, USA). At least 10,000 events were collected for each histogram. Cell cycle analysis was performed using a FACSCalibur flow cytometer (BD Biosciences, San Diego, CA, USA). Data analysis was performed using WinMDI version 2.9 (The Scipps Research Institute, San Diego, CA, USA).

Protein isolation andwestern blot analysis. The cells werelysed in radioimmunoprecipitation assay buffer (Biosesang, Inc., Sungnam, Korea) and protein concentrations were determined using a bicinchoninic acid assay. Protein lysates (20-30 $\mu \mathrm{g})$ were separated by SDS-PAGE (10-12\%), then electrophoretically transferred onto polyvinylidene fluoride membranes. The membranes were incubated for $1 \mathrm{~h}$ in $5 \%$ bovine serum albumin (Bioshop Canada Inc., Burlington, ON, Canada) in Tris-buffered saline (TBS)-Tween 20 at room temperature and washed 4 times for 15 min with TBS-Tween 20. Specific proteins were sequentially blotted with primary antibodies against Livin (cat. no. 5471), phosphorylated (phospho)-Akt (cat. no. 4060), phospho-extracellular signal-regulated kinase (ERK) 1/2 (cat. no. 4370), phospho-p38 (cat. no. 4511), phospho-c-Jun N-terminal kinase (JNK; cat. no. 4511), Akt (cat. no. 4691), ERK1/2 (cat. no. 4695), p38 (cat. no. 9212), JNK (cat. no. 9258), c-myc (cat, no. 9402), cyclin D1 (cat. no. 2926), cyclin D3 (cat. no. 2936), cyclin-dependent kinase (CDK)4 (cat. no. 2906), CDK6 (cat. no. 3136), p21 (cat. no. 2946), p27 (cat. no. 2552), $\beta$-actin (cat. no. 4970) obtained from Cell Signaling Technology, Inc. (Danvers, MA, USA), and glyceraldehyde 3-phosphate dehydrogenase (GAPDH; cat. no. sc-25778) antibody from Santa Cruz Biotechnology, Inc. (Dallas, TX, USA). The primary antibody against Livin detects Livin $\alpha(36 \mathrm{kDa})$ and Livin $\beta(34 \mathrm{kDa})$. Primary antibodies were diluted 1:1,000 and incubated with membranes for $24 \mathrm{~h}$ at $4^{\circ} \mathrm{C}$. Anti-rabbit (cat. no. 7074; Cell Signaling Technology, Inc.) or anti-mouse horeseradish peroxidase (HRP)-conjugated secondary antibodies (cat. no. 7076, Cell Signaling Technology, Inc.) were diluted 1:2,000 and incubated with membranes at room temperature for $2 \mathrm{~h}$. Immunoreactive proteins were visualized using an enhanced chemiluminescence detection system with a HRP (EMD Millipore, Billerica, MA, USA), and were analyzed using an LAS-4000 luminescent image analyzer (Fujifilm, Tokyo, Japan).

RNA isolation and reverse transcription-polymerase chain reaction $(R T-q P C R)$. Total RNA was extracted from the cells using TRIzol reagent (Invitrogen; Thermo Fisher Scientific, Inc.) according to the manufacturer's protocol. RT was performed using $1 \mu \mathrm{g}$ total RNA, M-MLV RT (Invitrogen; Thermo Fisher Scientific, Inc.), $1 \mu 110 \mathrm{mM}$ dNTP mix (Enzynomics Co., Ltd., Daejeon, Korea), $1 \mu \mathrm{l}$ oligo dT $(500 \mu \mathrm{g} /$ $\mathrm{ml}$; Promega Corporation, Madison, WI, USA), $2 \mu 10.1 \mathrm{M}$ dithiothreitol (Invitrogen; Thermo Fisher Scientific, Inc.), $4 \mu 1$ 5X First-strand buffer (Invitrogen; Thermo Fisher Scientific, Inc.) and $1 \mu \mathrm{l}$ RNase inhibitor (Promega Corporation). The cDNA was then amplified using specific primers for Livin and GAPDH (Bioneer Corporation, Daejeon, Korea), as previ- 

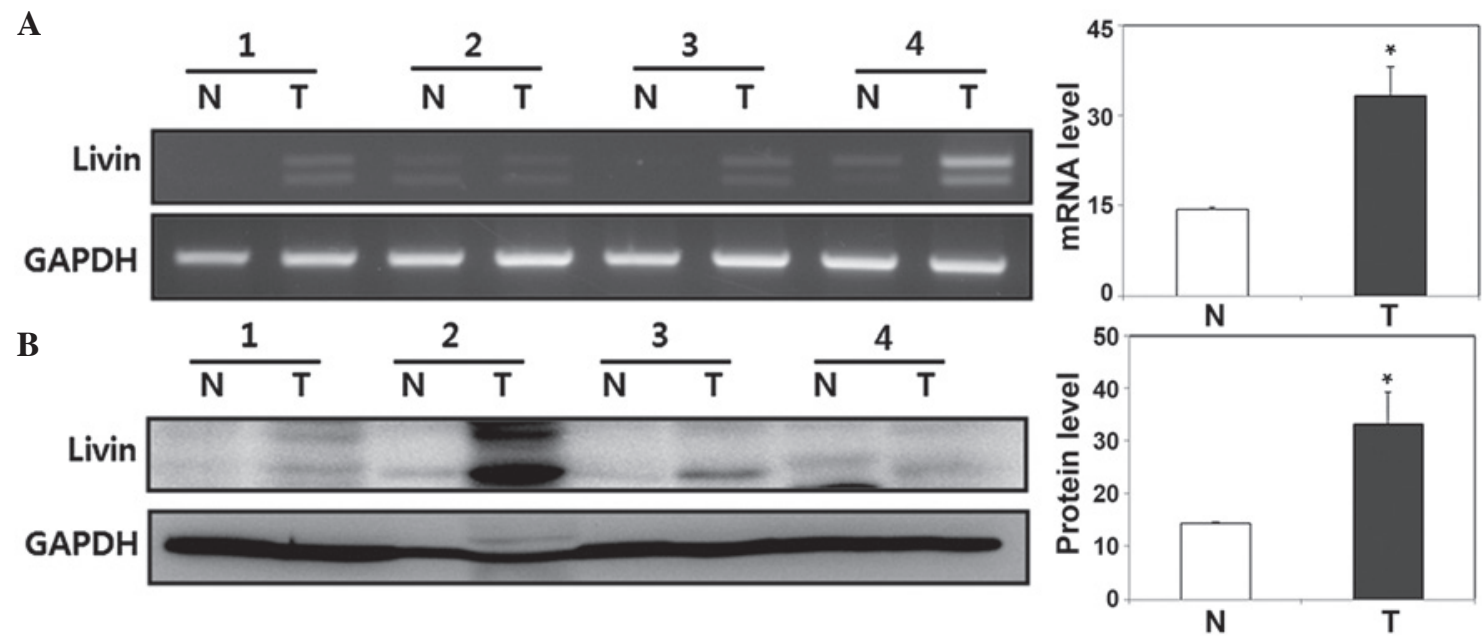

Figure 1. Expression of Livin in human HSCC tissues from the four patients (1-4). (A) mRNA expression levels of Livin, measured using reverse transcription-polymerase chain reaction analysis were significantly higher in HSCC tissues, compared with normal hypopharyngeal mucosal tissues. (" $\mathrm{P}=0.02$ ). (B) Protein expression levels of Livin, measured using western blot analysis, were significantly higher in HSCC tissues, compared with normal hypopharyngeal mucosa tissues $(" \mathrm{P}=0.04)$. Values are presented as the mean \pm standard error. HSCC, hypopharyngeal squamous cell carcinoma; N, normal tissues; $\mathrm{T}$, tumor tissues.

ously described (15). PCR was performed using GoTaq DNA Polymerase and 5X Green GoTaq reaction buffer (Promega Corporation) The primer sequences were as follows: Livin $\alpha$ and Livin $\beta$, forward 5'-CAC ACA GGC CAT CAG GAC AAG-3' and reverse 5'-ACG GCA CAA AGA CGA TGG AC-3' and GAPDH, forward 5'-ACC ACA GTC CAT GCC ATC AC-3' and reverse 5'-TCC ACC ACC CTG TTG CTG TA-3'. The PCR was performed by initial incubation at $94^{\circ} \mathrm{C}$ for 5 min followed by 32 cycles of $94^{\circ} \mathrm{C}$ for $30 \mathrm{sec}, 58^{\circ} \mathrm{C}$ for $20 \mathrm{sec}$ and $72^{\circ} \mathrm{C}$ for $30 \mathrm{sec}$, with a final elongation step of $72^{\circ} \mathrm{C}$ for $7 \mathrm{~min}$. The PCR products were separated by electrophoresis on a $1 \%$ agarose gel containing ethidium bromide. The signals were quantified by densitometric analysis using Labworks Image Acquisition software (UVP, Inc., Upland, CA, USA).

Statistical analysis. The significance of experimental differences were assessed using Student's $t$-test. The statistical software program used was SigmaPlot Software version 6.0 (Systat Software, San Jose, CA, USA). P $<0.05$ was considered to indicate a statistically significant difference.

Ethical considerations. Local research ethics committee approval was obtained from the Chonnam National University Hwasun Hospital Institutional Review Board.

\section{Results}

Expression of Livin is higher in human HSCC tissues, compared with normal hypopharyngeal mucosa tissues. The present study measured the expression of Livin at the mRNA and protein levels using RT-qPCR and western blot analyses in fresh human HSCC tissues and paired normal hypopharyngeal mucosal tissues. The expression of Livin was increased in the HSCC tissues. Compared with the paired normal hypopharyngeal mucosal tissues at the mRNA and protein levels $(\mathrm{P}<0.05$; Fig. 1).

Knockdown of Livin suppresses tumor cell growth in the human SNU-1041 HSCC cell line. To examine the role of
Livin in tumorigenesis, the present study used siRNA to inhibit the endogenous expression of Livin in the human SNU-1041 HSCC cell line. The mRNA and protein levels of Livin $\alpha$ and Livin $\beta$ were lower in the Livin siRNA-treated SNU-1041 cells, compared with those in the negative control siRNA-treated cells (Fig. 2A).

Knockdown of Livin significantly decreases cell proliferation in human HSCC cells. The number of proliferating cells, as determined by absorbance, was significantly lower in the Livin siRNA-transfected SNU-1041 cells, compared with the negative control siRNA-transfected SNU-1041 cells at $72 \mathrm{~h}$ post-transfection $(\mathrm{P}<0.05$; Fig. $2 \mathrm{~B})$.

Knockdown of Livin induces cell cycle arrest at the $G_{1}$ phase in human HSCC cells. Based on cell cycle analysis, Livin knockdown resulted in arrest at the $\mathrm{G}_{1}$ phase of the cell cycle in the SNU-1041 cells (Fig. 2C). The expression levels of cyclin D1, cyclin D3, CDK4, and CDK6, which are all key molecules for the $\mathrm{G}_{1}$ phase transition, were significantly decreased by Livin knockdown in the SNU-1041 cells (Fig. 2D). The expression of c-myc was also decreased, however, the CDK inhibitors, p21 and p27, were not altered by Livin knockdown in the SNU-1041 cells. These results indicated that Livin knockdown induced cell cycle arrest through the modulation of cell cycle-positive regulators, including c-myc, cyclin D1, cyclin D3, CDK4 and CDK6.

Knockdown of Livin decreases the phosphorylation of MAPK signaling proteins and Akt in human HSCC cells. To examine the potential mechanisms involved in the effects of Livin, the present study examined the impact of Livin on the MAPK/Akt signaling pathways, which are essential for cell growth and survival. The phosphorylation levels of ERK1/2, p38, JNK and Akt were decreased by Livin knockdown in the SNU-1041 cells (Fig. 3). The levels of total ERK1/2, p38, JNK and Akt were not affected by Livin knockdown in the SNU-1041 cells. 
A

C

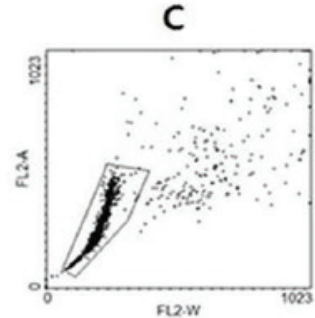

L

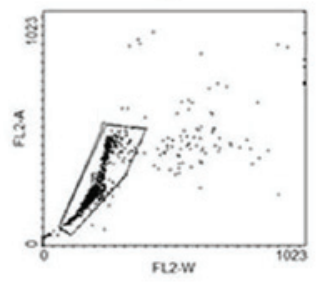

c
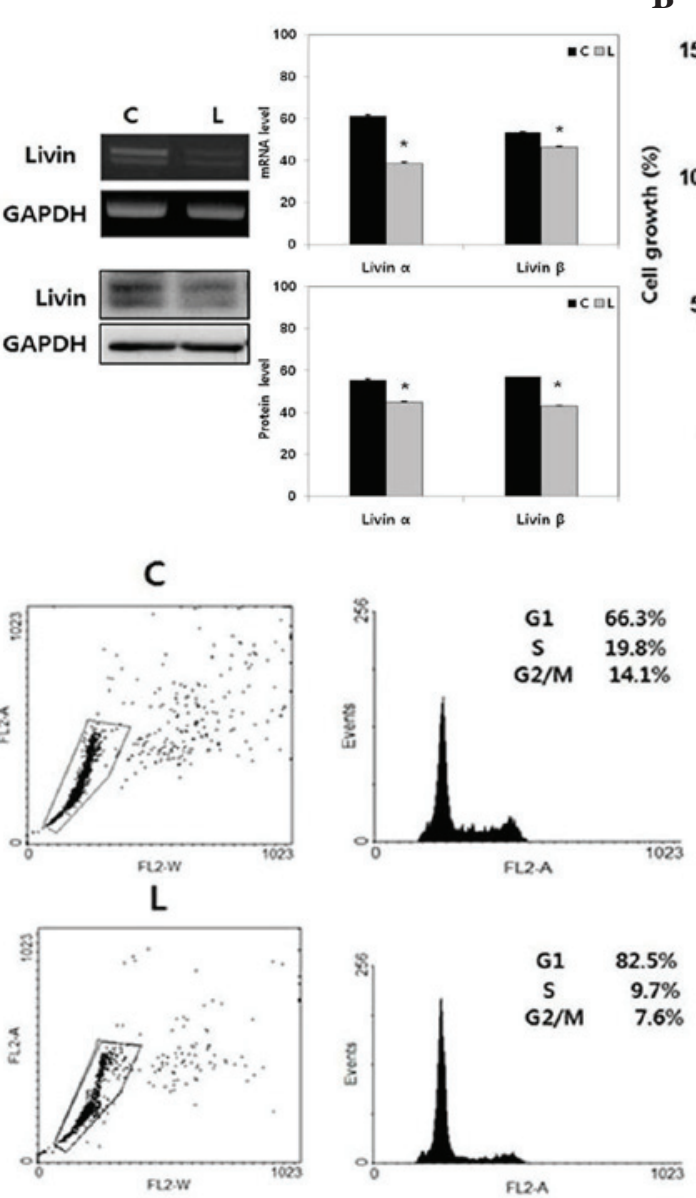

B

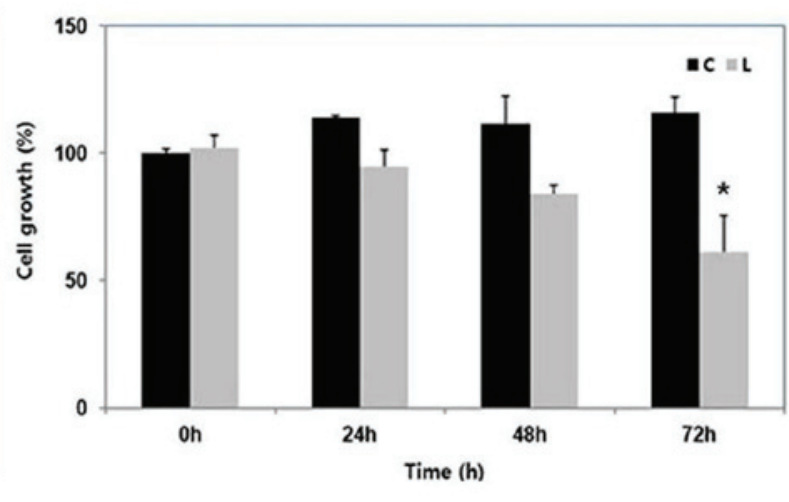

D

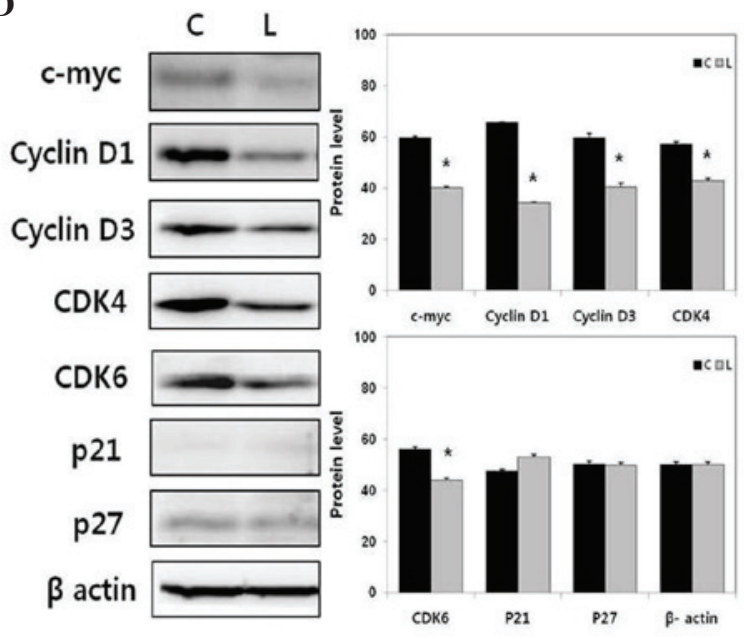

Figure 2. Effect of Livin knockdown on HSCC cell proliferation and cell cycle. (A) mRNA and protein expression levels of Livin $\alpha$ and Livin $\beta$ were decreased by siRNA-mediated Livin knockdown in the SNU-1041 cells. (B) Livin knockdown inhibited SNU-1041 proliferation. Values are presented as the mean \pm standard error. " $\mathrm{P}<0.05$ vs. C. (C) Livin knockdown induced cell cycle arrest at the $\mathrm{G}_{1}$ phase in the SNU-1041 cells. (D) Livin knockdown decreased the expression levels of cell cycle-positive regulators, c-myc, cyclin D1, cyclin D3, CDK4, and CDK6 in the SNU-1041 cells. *P<0.01 vs. C. HSCC, hypopharyngeal squamous cell carcinoma; CDK, cyclin-dependent kinase; GAPDH, glyceraldehyde 3-phosphate dehydrogenase; siRNA, small interfering RNA; C, negative control siRNA-transfected SNU-1041 cells; L, Livin siRNA-transfected SNU-1041 cells.

\section{Discussion}

IAPs have been identified in organisms ranging from yeast to mammals (6). Human IAP family members include neuronal apoptosis inhibitory protein, cellular (c)-IAP1, c-IAP2, X-linked XIAP, Survivin, Apollon, IAP-like protein 2 and Livin (5-7,16-19). These proteins contain one or more baculovirus IAP repeat (BIR) domains and harbor a $\mathrm{COOH}$-terminal RING finger domain $(6,7)$. It is generally considered that the BIR domain is required for the suppression of apoptosis by IAPs $(20,21)$. Livin is a $39-\mathrm{kD}$ a protein consisting of a single BIR domain and a RING motif, encoded by a gene spanning $4.6 \mathrm{~kb}$ on chromosome 20 at band q13, and composed of six introns and seven exons (5). Livin has been reported to inhibit tumor cell apoptosis $(10,22)$. Furthermore, Livin has been implicated in the promotion of cell survival, and in the regulation of proliferation and the cell cycle (22). However, the impact of Livin on human HSCC cell behavior remains to be elucidated.

Elevated expression of Livin has been found in tumors, including melanoma, breast cancer, colon cancer, prostate cancer and hepatoma (8-10). These findings suggest that
Livin may contribute to tumorigenesis. In the present study, upregulation in the expression of Livin was observed in fresh HSCC tissues, compared with paired normal mucosal tissues at the mRNA and protein levels, although the sample size of patients was small. Additionally, the present study showed that knockdown of Livin suppressed tumor cell proliferation and led to cell cycle arrest in human HSCC cells. Cell cycle promotion with apoptosis resistance is important in tumor development and progression $(23,24)$. The cell cycle is positively regulated by a family of cyclins and CDKs, and negatively regulated by CDK inhibitors, including p 21 and p27 (24). Livin knockdown induced the suppression of c-myc, cyclin D1, cyclin D3, CDK4, and CDK6 in human HSCC cells. These results indicated that Livin induced tumorigenic activities, including cell proliferation and cell cycle promotion in the human HSCC.

Livin is considered to be a genuine apoptosis inhibitor due to its direct association with caspase-3 and caspase-7, as well as its ability to counteract cell death by interfering with caspase-9 processing (25). In our previous study, it was reported that Livin inhibits cell apoptosis via the modulation of caspase 3, caspase 7 and poly ADP ribose polymerase in 

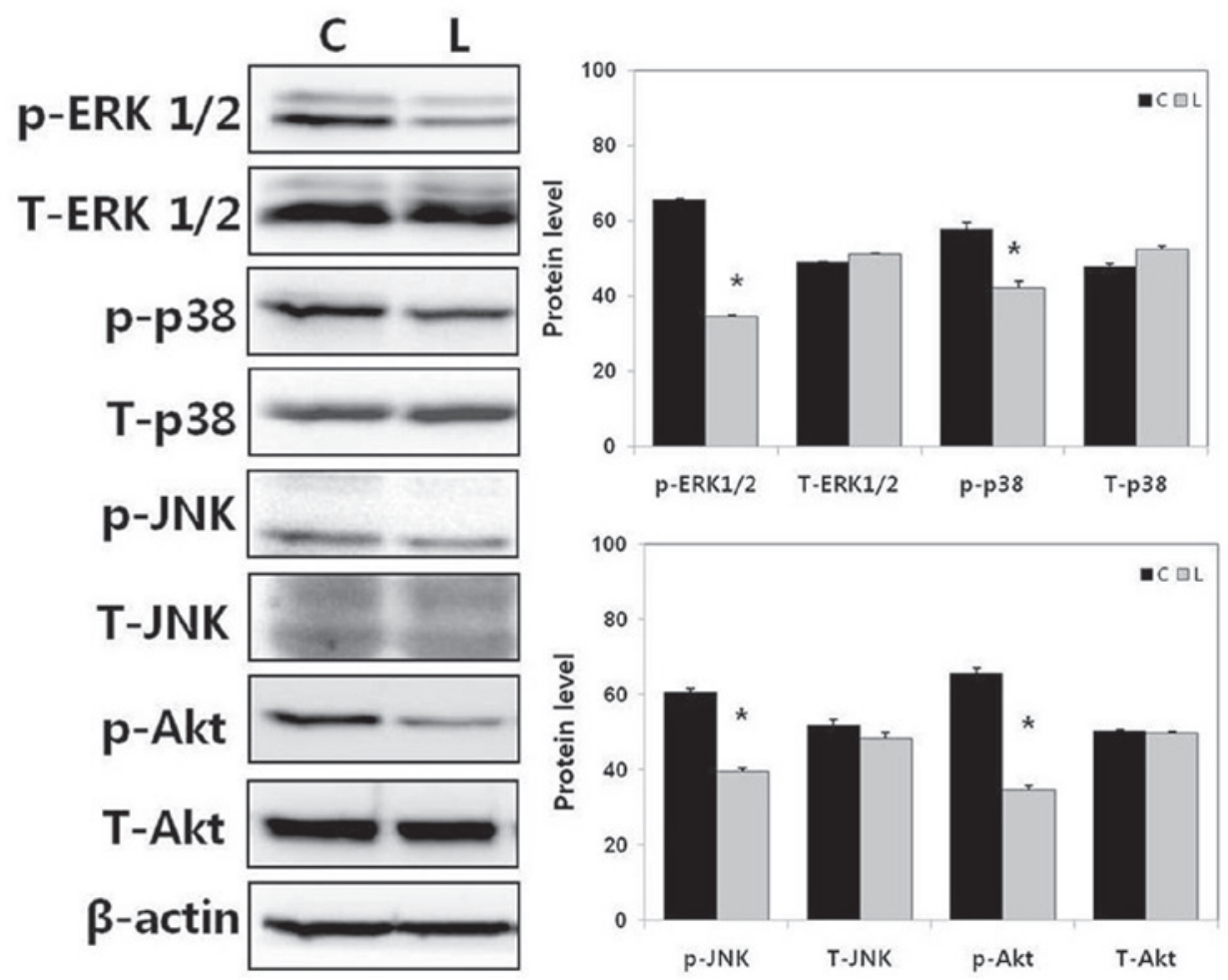

Figure 3. Effect of Livin knockdown on MAPK and Akt signaling pathways in human HSCC cells. The phosphorylation levels of ERK1/2, p38, JNK, and Akt were decreased by Livin knockdown in SNU-1041 cells. ${ }^{*} \mathrm{P}<0.01$ vs. C. HSCC, hypopharyngeal squamous cell carcinoma; ERK, extracellular signal-regulated kinase; MAPK, mitogen-activated protein kinase; JNK, c-Jun N-terminal kinase; siRNA, small interfering RNA; p-, phosphorylated; C, negative control siRNA-transfected SNU-1041 cells; L, Livin siRNA-transfected SNU-1041 cells.

human laryngohypopharyngeal squamous cell carcinoma cells (15). Although the majority of studies on Livin have focused on its role as a caspase inhibitor, there is increasing evidence that it also acts through other mechanisms $(26,27)$. Chen et al reported that Livin abrogates apoptosis of lung adenocarcinoma cells by regulating the JNK signaling pathway (26). It has also been reported that Livin enhances JNK phosphorylation, and that activated JNK antagonizes tumor necrosis factor $\alpha$ and interleukin-converting enzyme-induced apoptosis (27). MAPK/Akt signaling is involved in several cellular programs, including cell proliferation, migration, survival and differentiation $(11,12)$. The present study showed that Livin knockdown inhibited the phosphorylation of ERK1/2, p38, JNK and Akt in the human HSCC cells. To the best of our knowledge, the present study is the first investigation to describe the effects of Livin knockdown on ERK1/2, p38 and Akt in cancer cells. These findings suggested that Livin may promote tumor cell invasiveness by activating the MAPK/Akt signaling pathways in human HSCC.

In conclusion, Livin knockdown suppressed cell proliferation and induced cell cycle arrest via the modulation of cell cycle regulatory proteins in human HSCC cells. Livin knockdown also reduced the activation of the MAPK/Akt signaling proteins, including ERK1/2, p38, JNK and Akt in human HSCC cells. Although further investigations are required to support these findings, the results of the present study suggested that Livin may enhance tumorigenesis by modulating the MAPK/Akt signaling pathways in human HSCC.

\section{Acknowledgements}

This study was supported by a grant (grant no. CRI 13013-1) from the Chonnam National University Hospital Biomedical Research Institute. The authors would like to thank Dr. Sung (Seoul National University) for providing the SNU-1041 cell line.

\section{References}

1. Jemal A, Siegel R, Ward E, Hao Y, Xu J and Thun MJ: Cancer statistics, 2009. CA Cancer J Clin 59: 225-249, 2009.

2. Sewnaik A, Hoorweg JJ, Kneqt PP, Wieringa MH, van der Beek JM and Kerrebijn JD: Treatment of hypopharyngeal carcinoma: Analysis of nationwide study in the Netherlands over a 10-year period. Clin Otolaryngol 30: 52-57, 2005.

3. Gupta T, Chopra S, Aqarwal JP, Laskar SG, D'cruz AK, Shrivastava SK and Dinshaw KA: Squamous cell carcinoma of the hypopharynx: Single-institution outcome analysis of a large cohort of patients treated with primary non-surgical approaches. Acta Oncol 48: 541-548, 2009.

4. Semrau R, Mueller RP, Stuetzer H, Staar S, Schroeder U, Guntinas-Lichius O, Kocher M,Eich HT, Dietz A, Flentje M, et al: Efficacy of intensified hyperfractionated and accelerated radiotherapy and concurrent chemotherapy with carboplatin and 5-fluorouraceil: Updated results of a randomized multicentric trial in advanced head-and-neck cancer. Int J Radiat Oncol Biol Phys 64: 1308-1316, 2006.

5. Ashhab Y, Alian A, Polliack A, Panet A and Ben Yehuda D: Two splicing variants of a new inhibitor of apoptosis gene with different biological properties and tissue distribution pattern. FEBS Lett 495: 56-60, 2001.

6. Deveraux QL and Reed JC: IAP family proteins-suppressors of apoptosis. Genes Dev 13: 239-252, 1999.

7. Deveraux QL, Stennicke HR, Salvesen GS and Reed JC: Endogenous inhibitors of caspases. J Clin Immunol 19: 388-398, 1999. 
8. Liu B, Han M, Wen JK and Wang L: Livin/ML-IAP as a new target for cancer treatment. Cancer Lett 250: 168-176, 2007.

9. Wang L, Zhang Q, Liu B, Han M and Shan B: Challenge and promise: Roles for Livin in progression and therapy of cancer. Mol Cancer Ther 7: 3661-3669, 2008.

10. Vucic D, Stennicke HR, Pisabarro MT, Salvesen GS and Dixit VM ML-IAP, a novel inhibitor of apoptosis that is preferentially expressed in human melanomas. Curr Biol 10: 1359-1366, 2000.

11. Keshet Y and Seger R: The MAP kinase signaling cascades: A system of hundreds of components regulates a diverse array of physiological functions. Methods Mol Biol 661: 3-38, 2010.

12. Pratilas CA and Solit DB: Targeting the mitogen-activated protein kinase pathway: Physiological feedback and drug response. Clin Cancer Res 16: 3329-3334, 2010.

13. Bermudez O, Pagès G and Gimond $\mathrm{C}$ : The dual-specificity MAP kinase phosphatases: Critical roles in development and cancer. Am J Physiol Cell Physiol 299: C189-C202, 2010.

14. Haagenson KK and Wu GS: Mitogen activated protein kinase phosphatases and cancer. Cancer Biol Ther 9: 337-340, 2010.

15. Lee DH, Yoon TM, Kim SA, Park YL, Lee KH, Lim SC, Lee JK and Joo YE: Relationship between expression of Livin and the biological behavior of human oral squamous cell carcinoma Oncol Rep 32: 2453-2460, 2014.

16. Badran A, Yoshida A, Ishikawa K, Goi T, Yamaguchi A, Ueda T and Inuzuka M: Identification of a novel splice variant of the human anti-apoptopsis gene survivin. Biochem Biophys Res Commun 314: 902-907, 2004.

17. Eckelman BP, Salvesen GS and Scott FL: Human inhibitor of apoptosis proteins: Why XIAP is the black sheep of the family. EMBO Rep 7: 988-994, 2006.

18. Roy N, Deveraux QL, Takahashi R, Salvesen GS and Reed JC: The c-IAP-1 and c-IAP-2 proteins are direct inhibitors of specific caspases. EMBO J 16: 6914-6925, 1997.
19. Vaux DL and Silke J: Mammalian mitochondrial IAP binding proteins. Biochem Biophys Res Commun 304: 499-504, 2003

20. Deveraux QL, Roy N, Stennicke HR, Van Arsdale T, Zhou Q, Srinivasula SM, Alnemri ES, Salvesen GS and Reed JC: IAPs block apoptotic events induced by caspase- 8 and cytochrome c by direct inhibition of distinct caspases. EMBO J 17: 2215-2223, 1998.

21. Deveraux QL, Takahashi R, Salvesen GS and Reed JC: X-linked IAP is a direct inhibitor of cell-death proteases. Nature 388: 300-304, 1997.

22. Cho SB, Lee WS, Park YL, Kim N, Oh HH, Kim MY, Oak CY, Chung CY, Park HC, Kim JS, et al: Livin is associated with the invasive and oncogenic phenotypes of human hepatocellular carcinoma cells. Hepatol Res 45: 448-457, 2015.

23. DeBerardinis RJ, Lum JJ, Hatzivassiliou G and Thompson CB: The biology of cancer: Metabolic reprogramming fuels cell growth and proliferation. Cell Metab 7: 11-20, 2008.

24. Graña X and Reddy EP: Cell cycle control in mammalian cells: Role of cyclins, cyclin dependent kinases (CDKs), growth suppressor genes and cyclin-dependent kinase inhibitors (CKIs). Oncogene 11: 211-219, 1995.

25. Kasof GM and Gomes BC: Livin, a novel inhibitor of apoptosis protein family member. J Biol Chem 276: 3238-3246, 2001.

26. Chen YS, Li HR, Lin M, Chen G, Xie BS, Xu NL and Lin LF: Livin abrogates apoptosis of SPC-A1 cell by regulating JNKI signaling pathway. Mol Biol Rep 37: 2241-2247, 2010.

27. Sanna MG, da Silva Correia J, Ducrey O, Lee J, Nomoto K, Schrantz N, Deveraux QL and Ulevitch RJ: IAP suppression of apoptosis involves distinct mechanisms: The TAK1/JNK1 signaling cascade and caspase inhibition. Mol Cell Biol 22: $1754-1766,2002$. 